\title{
Self Enlightenment in Woolf, Joyce, and Nietzsche
}

\author{
Gabriel V. Rupp \\ University of Central Oklahoma
}

Follow this and additional works at: https://docs.lib.purdue.edu/clcweb

Part of the Comparative Literature Commons, and the Critical and Cultural Studies Commons

Dedicated to the dissemination of scholarly and professional information, Purdue University Press selects, develops, and distributes quality resources in several key subject areas for which its parent university is famous, including business, technology, health, veterinary medicine, and other selected disciplines in the humanities and sciences.

CLCWeb: Comparative Literature and Culture, the peer-reviewed, full-text, and open-access learned journal in the humanities and social sciences, publishes new scholarship following tenets of the discipline of comparative literature and the field of cultural studies designated as "comparative cultural studies." Publications in the journal are indexed in the Annual Bibliography of English Language and Literature (Chadwyck-Healey), the Arts and Humanities Citation Index (Thomson Reuters ISI), the Humanities Index (Wilson), Humanities International Complete (EBSCO), the International Bibliography of the Modern Language Association of America, and Scopus (Elsevier). The journal is affiliated with the Purdue University Press monograph series of Books in Comparative Cultural Studies. Contact: <clcweb@purdue.edu>

\section{Recommended Citation}

Rupp, Gabriel V. "Self Enlightenment in Woolf, Joyce, and Nietzsche." CLCWeb: Comparative Literature and Culture 12.3 (2010): <https://doi.org/10.7771/1481-4374.1495>

This text has been double-blind peer reviewed by $2+1$ experts in the field.

The above text, published by Purdue University Press (CPurdue University, has been downloaded 2504 times as of $11 /$ $07 / 19$.

This document has been made available through Purdue e-Pubs, a service of the Purdue University Libraries. Please contact epubs@purdue.edu for additional information.

This is an Open Access journal. This means that it uses a funding model that does not charge readers or their institutions for access. Readers may freely read, download, copy, distribute, print, search, or link to the full texts of articles. This journal is covered under the CC BY-NC-ND license. 


\section{PURDUE}

UNIVERSITY PRESS <http://www.thepress.purdue.edu>

\section{CLCWeb: Comparative Literature and Culture}

ISSN 1481-4374 <http://docs.lib.purdue.edu/clcweb> Purdue University Press (C)Purdue University

CLCWeb: Comparative Literature and Culture, the peer-reviewed, full-text, and open-access learned journal in the humanities and social sciences, publishes new scholarship following tenets of the discipline of comparative literature and the field of cultural studies designated as "comparative cultural studies." In addition to the publication of articles, the journal publishes review articles of scholarly books and publishes research material in its Library Series. Publications in the journal are indexed in the Annual Bibliography of English Language and Literature (Chadwyck-Healey), the Arts and Humanities Citation Index (Thomson Reuters ISI), the Humanities Index (Wilson), Humanities International Complete (EBSCO), the International Bibliography of the Modern Language Association of America, and Scopus (Elsevier). The journal is affiliated with the Purdue University Press monograph series of Books in Comparative Cultural Studies. Contact: <clcweb@purdue.edu>

\section{Volume 12 Issue 3 (September 2010) Article 8 Gabriel V. Rupp, "Self Enlightenment in Woolf, Joyce, and Nietzsche" <http://docs.lib.purdue.edu/clcweb/vol12/iss3/8>}

Contents of CLCWeb: Comparative Literature and Culture 12.3 (2010)

<http://docs.lib.purdue.edu/clcweb/vol12/iss3/>

Abstract: In his article "Self Enlightenment in Woolf, Joyce, and Nietzsche" Gabriel V. Rupp analyzes texts drawn from late nineteenth and early twentieth centuries, a critical period of change characterized by an explosive set of dramatic, historically unique, and complicated transformations in society and technology. Rupp argues that in Virginia Woolf's Mrs. Dalloway, in James Joyce's Dubliners and Portrait of the Artist as a Young Man, and in Friedrich Nietzsche's last three "strangely beautiful but mad" letters (Kaufmann), these writers' self enlightenment of a unified and discrete self is disrupted, calling into question simultaneously the constructed nature of that unity of self while also exposing certain limits inherent in such a chaotic, polyvocal, and "schizophrenic" conception of consciousness. By applying Niels Bohr's complementarity as a potential reframing of those limits, Rupp suggests that a form of ethical subjectivity, i.e., self enlightenment, can be recovered in the texts analyzed. 


\section{Gabriel V. RUPP}

\section{Self Enlightenment in Woolf, Joyce, and Nietzsche}

The late nineteenth and early twentieth centuries were witness to an explosive set of dramatic and historically unique and complicated transformations in society and technology. Underlying these changes was a discernible shift in the manner in which we understood and presented who and what the human is. Stephen Kern, in The Culture of Time and Space: 1880-1918, writes that "From around 1880 to the outbreak of World War I a series of sweeping changes in technology and culture created distinctive new modes of thinking about and experiencing space and time. Technological innovations including the telephone, wireless telegraph, $\mathrm{x}$-ray, cinema, bicycle, automobile, and airplane established the material foundation for this reorientation: independent cultural developments such as stream-of consciousness novel, psychoanalysis, Cubism, and the theory of relativity shaped consciousness directly. The result was a transformation of the dimensions of life and thought" (1-2).

My objective in the present study is to examine a number of texts drawn from the said critical period of change in which some of "the transformations of the dimensions of life and thought" of which Kern speaks are brought to the fore. My argument is that in Virginia Woolf's Mrs. Dalloway, in James Joyce's Dubliners and Portrait of the Artist as a Young Man, and in Friedrich Nietzsche's last three "strangely beautiful but mad" letters (Kaufmann, "Letters" 684), these writers' self enlightenment of a unified and discrete self is disrupted, calling into question simultaneously the constructed nature of that unity of self while also exposing certain limits inherent in such a chaotic, polyvocal, and "schizophrenic" conception of consciousness. By applying Niels Bohr's complementarity as a potential reframing of those limits, I argue that that a form of ethical subjectivity, i.e., self enlightenment, can be recovered in the texts analyzed.

My choice of Bohr's concept of complementarity - a kind of post-Newtonian framework - is based on a number of considerations. First, Bohr, in many ways a "father" of modern quantum physics, begins to develop his framework to account for new findings in the hard sciences at roughly the same time writers such as Woolf, Joyce, and Nietzsche do their work and thus Bohr is located within the same culture characterized by changes in the sense of space and time of which Kern speaks. Second, Bohr's complementarity, like Werner Heisenberg's principle of uncertainty, Kurt Gödel's incompleteness theorem, or even J.S. Bell's theorem, is a post-Newtonian response to increasingly numerous experimental and conceptual anomalies, to use Thomas Kuhn's term. Where Bohr differs from the others is in his more sustained effort to go beyond attempts to account for perplexing experimental observations and extend his framework to the very ways we know the world, and the various truthvalue constitutions in which those ways of knowing are implicated. Alhough I am not ready to argue, as Arkady Plotnitsky does in his Complementarity: Anti-epistemology after Bohr and Derrida, that Bohr's complementarity is an anti-epistemological system that combines George Bataille's general economic model with Jacques Derrida's post-structural deconstruction. Rather, I am operating on the assumption that complementarity operates distinctly differently than other systems of representation in the sciences, including Albert Einstein's general relativity in that it responds to what Kern calls the "Abundance" - in developments and transformations in the arts, sciences, technologies, economies of the late Enlightenment and modern periods, and that Ronald Schleifer argues demanded "new ways of making sense out of experience, whose confusions weren't the result of need and dearth ... but whose confusions stemmed from those difficulties that arise from abundance and plenty" (36). Schleifer situates Heisenberg's mode of understanding suggested by the uncertainty principle within the larger context of late-modern abundance as an example of a "post-Newtonian physics as the pursuit of multiple 'alternating' descriptions and 'retrospective' description rather than categorizing phenomena in terms of simple reductive principle" (48). Similarly, I view Bohr's efforts as non-reductive and retrospectively descriptive, but see, as well, in Bohr deliberate extension of his approach to account for not just other phenomena but more interestingly, more systems, even those seemingly contradictory or opposed to one another that purport to define what constitutes phenomena in the first place. In brief, I am applying complementarity as a frame to approach the selected texts by Woolf, Joyce, and Nietzsche in respective narrations of two binaries or oppositions that emerge in the texts and I designate (uneasily) as "the self construct," "the self-other and sanity-madness," or "self-other." 
Michel Foucault, in his Care of the Self, presents Greek thought providing evidence of selfregulating discursive statements reflecting and giving rise to a sense of a discrete "self," that is, of an internalized self construct. It is only in the Enlightenment, however, that this felt-as whole-andseparate-from-others mode of a conceptualization of the self is fully developed as internalized selfregulation - the "mode of subjectification" - and become thoroughly entangled, at one level, in Cartesian mechanization and reflected in such emerging cultural forces as psychiatrization, criminalization, and sexualization, all of which locate deviance not in what one does but ultimately in what one is, one's "self." This self is "social" only in the sense that it is an internal representation of social expectations - it is the "subject" of the rules of society. At its extreme, it is ruled completely and also a "ruler" in that it both is a measure of social requirements, one that also rules itself. A good example of a literary demonstration of a rule-bound situation of self enlightenment is in Daniel Defoe's Robinson Crusoe. Almost any random selection from the novel will do, but the following quote is especially apt as it introduces a binarized list of "good" and "evil" - a ledger of debt and credit: "I now began to consider seriously my condition, and in the circumstance I was reduced to, and I drew up the state of my affairs in writing, not so much to leave them to any that were to come, for I was like to have few heirs, as to deliver my thoughts daily from poring upon them. And afflicting my mind: and as my reason began now to master my despondency, I began to comfort myself as well I could, and to set the good against the evil, that I might have something to distinguish my case from worse, and I stated it very impartially, like a debtor and creditor, the comforts I enjoyed against the miseries I suffered" (83).

Note the mechanistic overtones, reminiscent of the psyche George Campbell employs in the nineteenth century to describe how rhetoric works with the mechanized "mind" (see Golden and Corbett 139-260). Reason "masters" despondency, rules his feelings. This mastery is Bruno Latour's twin tasks of the Enlightenment - "domination and emancipation" - applied directly to the construct of the self. Crusoe would free that self of its "bad" feelings by domination through "good reason," whatever that may be. He is cloaked in a veneer of impartiality even about his own "subjectivity." He experiences less his feelings than reports them dryly and he makes of his human condition a kind of economic endeavor. The self is made into a "thing," to be managed, mastered, ruled, controlled. And throughout the novel, Crusoe never questions his world view: he is civilized; the natives he contacts are savages - in large part, as developed in the case of Friday, because they have not yet understood the "self" that they have to care for. Crusoe, of course, will teach them - and rule not only their minds but also their Island. Additionally, the manner in which he speaks, the first-person reporting narrator, also reflects a tight control and a strict unquestioned separation from the self other, inside and outside. In contrast to this unified, mastered, and controlled version of the self is the following from Joyce's story "Clay" in Dubliners: "The matron had given her leave to go out as soon as the women's tea was over and Maria looked forward to her evening out. The kitchen was spick and span: the cook said you could see yourself in the big copper boilers. The fire was nice and bright and on one of the side table were four very big barmbacks. These barmbacks seemed uncut; but if you went closer you would see that they had been cut into long thick even slices and were ready to be handed round at tea. Maria had cut them herself. Maria was a very small person indeed but she had a very long nose and a very long chin. She talked a little through her nose, always soothingly: Yes, my dear, and No, my dear. She was always sent for when the women quarreled over their tubs and always succeeded in making peace" (99).

From the outset, Joyce's prose reads oddly in comparison to Defoe's. Gone is the clear sense of who is telling the story; it begins in third person, shifts then to second person, then shifts back to third person. Along the way, even the sentence level style is textured differently. The frequent compounding - the endless "ands" - suggest less flow of the narrative of a story told from a distance than the act of thought itself, far closer to aggregatizing orality than subordinating literacy. The deployment of the passive voice, in contrast, is extra-distancing. Throughout, because of Joyce's free and indirect discourse, we never get a sense of a unified narrator telling the story. However, this narrator feels less hidden than smeared across the shifting perspectives. The "self, " in this demonstration, is coming undone, and indeed feels more like a series of doings. Woolf, as well, reveals a similar kind of fragmentation: 
How fresh, how calm, stiller than this of course, the air was in the early morning; chill and sharp and yet (for a girls of eighteen as she was them) solemn, feeling as she did, standing there at the open window, that something awful was about to happen; looking at the flowers, at the trees with the smoke winding off them and the rooks rising, falling; standing and looking until peter Walsh said, Musing among the vegetables - was that it? I prefer men to cauliflowers - was that it? She stiffened a little on the curb, waiting for Durtnell's van to pass. A charming woman, Scrope Purvis thought her (knowing her as one does know people who live next door to one in Westminster); a touch of the bird about her, of the jay, blue green, light, vivacious, even though she was over fifty, and grown very white since her illness. (Mrs. Dalloway 3-4)

In this passage, Woolf is also moving far beyond Defoe's presentation of a unified self as did Joyce in the prior passage, but she does it differently. Note the same compounding, now effected via the semicolon instead of Joyce's coordinate conjunction "and." Additionally, the dashed segments demonstrate the interrupted, digressive, associational quality of thought. Woolf is far beyond Defoe's "perspicuitous" reportage: like in Joyce, the narrative center refuses to remain still, but unlike Joyce, Woolf marks the speaker as she does with the Purvis shift. Throughout the narrative, Woolf shifts with grace and fluidity from one person's perspective to another and the move from perspective to perspective matches also the physical movements of the characters through space. Within a Bohrian framework, both Joyce's and Woolf's moves can be framed as a number of complements, mutually exclusive and yet interdependent, all of which could be said to be framed within the larger complement of self and other. Inner and outer worlds, for example, are presented as alternating descriptions, yet neither dominates, or seems valorized, over the other. Reality, it seems, is in the I's and the eyes of the beholders, but what a legion of beholders! Clear separations, such as self and other, no longer make sense in a manner of self enlightenment. Human experience cannot be reduced to such a binary as self or other, but can be described exhaustively through a set of alternations of reference frames. Similarly, and more frighteningly, Nietzsche's three letters reveal the same kind of complementarity between self and other. Nietzsche writes in his letter to Jacob Burckhardt: "I am Prado. I am also the father of Prado; I dare say that I am Lessups too. I wanted to give my Parisians, whom I love, a new notion: that of the decent criminal. I am also Chambrige - also a decent criminal ... What is disagreeable and offends my modesty is that at the bottom I am every name in history. This fall I was twice blinded as little as possible when I twice witnessed my own funereal, first as Count Alberto (no, that is my son, insofar as I am Carlo Alberto, unfaithful to my nature); but Antonelli I was myself" ("Letter" 686).

The people to whom Nietzsche refers in the first paragraph are all people in the news of his time: Prado and Chambridge, for example, are convicted murders about whom he wrote in other correspondences. Note how he identifies with one and then the other - and then grumbles about identification with all people. Also, like Woolf, he interrupts himself, adding yet another identification. He also signs his last three letters with different names: Nietzsche on this one, The Crucified on the second, and finally Dionysus on the third. What strikes me about the first letter in particular, however, is a postscript he writes in the margins: "I go everywhere in my student's coat, and here and there slap somebody on the shoulder and say, Siamo contenti? Son dio ho fatto questa carcatura. (Are we content? I am the god who has made this caricature) ("Letters" 687). Given Nietzsche's radical perspectivism, defined here as his utter dispensation with anything like a source or center of value, as outlined in his Genealogy of Morals, his three part reply to Kant's three critiques of pure reason, practical reason, and judgment, and in Ecce Homo, his autobiographical intertextualization of the bulk of his philosophy, this comment seems an ironic rhetorical question. He, as god, as the anti-Prometheus who leaves instead the company of the real creators - folks themselves - has carried fire back to the constructed gods. But it is there, I suspect, that he stops - in the fire. When the power of construction of reality is taken away not just from the literal gods of Christ and Buddha, for example, but from the more subtle secular gods of Enlightenment - objectivity, rationalism, reason, as a partial pantheon - what replaces them? How, for Zarathustra's sake, do we live? Can we be held responsible for anything when the very concept of responsibility has been demonstrated to conceal a more deadly agenda of domination - of the self and the world? This conundrum could all be perhaps explained away as a series of last minute Nietzschisms, were it not for the fact that these letters are the end, written between the time he breaks down after embracing a horse he sees whipped in the streets and 
his commitment to a mental institution. As I argue next, Nietzsche's "real" madness, as also in the more fictive madnesses in Joyce and Woolf, is a lived elaboration of his exploring the limits not just of Enlightenment thinking, but of its Bohrian complement: post-Enlightenment thought.

The traditional story of Nietzsche's madness is that it was caused by tertiary syphilis. Walter A. Kaufmann, in his "Introduction" to The Portable Nietzsche, notes: "His madness was in all probability an atypical general paresis. If so, he must have had syphilis; and since he is known to have lived a highly ascetic life, it is supposed that, as a student, he had visited a brothel once or twice. This has never been substantiated, and any detailed accounts of such experiences are either poetry or pornography - not biography. Nor has the suggestion ever been disproved that he may have been infected while nursing soldiers in 1870" (13-14). I find the default acceptance of Nietzsche's madness as so neatly placed within today's psychiatric context - without a shred of evidence other than an assumption of symptom -ironic, given Nietzsche's great elaborator Foucault sustained critique of the process of psychiatization as a system of deadly constructions. Further, this disorder is decidedly a "physical" category: paresis is an "organic" psychosis, a problem divorced from psychological or social factors. The "poetry or pornography" comment is telling: Kaufman sees these two responses as obvious constructions, but then accepts the illness as unconstructed. My own suspicion is that Nietzsche's madness can be just as readily explained as a kind of philosophical paresis, where his endless interrogation, his spirochete method, ran like a fever through his own sense of "subject," and it was his recognition that this method, let loose as an infection on all philosophizing, can have deadly consequences. Consider his very last letter: "To friend Overbeck and wife. Although you have so far demonstrated little faith in my ability to pay, I yet hope to demonstrate that I am somebody who pays his debts-for example, to you. I am just having all anti-Semites shot. Dionysus" ("Letters" 687).

Considering how not just Nietzsche's ideas but his very body, blasted empty of a "self" with any sort of unity, were appropriated both figuratively and literally by his sister to create a cult of Nietzschism that was used to help set in play the very ideological forces that would result in over six million Jewish folk mechanically and methodologically killed, this letter, the last words he ever wrote, takes on a horrible significance. It was already too late for his words to have the constructing effect of "having all anti-Semites" shot; his last letter is a cry for response - ability, only to be followed by a decade of silence, and then death. Joyce also provides descriptions of what could be madness, if madness is a kind of dissolution of the self. The following is near the end of "The Dead": "Generous tears filled Gabriel's eyes. He had never felt like that himself towards any woman but he knew that such a feeling must be love. The tears gathered more thickly in his eyes and in the partial darkness he imagined he saw the form of a young man standing under a dripping tree. Other forms were near. His soul approached that region where dwelt the vast hosts of the dead. He was conscious of, but could not apprehend, their wayward and flickering existence. His own identity was fading out into a grey impalpable world: the solid world itself which these dead had one time reared and lived was dissolving and dwindling" (223). This set of perceptions is a less dramatic madness than Nietzsche's demonstrated by Septimus in Mrs. Dalloway, but it still reflects the sense of dissolution of the self that characterizes both the insane and the mystical. In fact, Joyce's concept of epiphany, particularly in Portrait of the Artist where it is linked more specifically with an esthetics, is Joyce's "resolution" both of the self-other and the sanity-madness binary. However, what characterizes Joyce's fictional approach - as what characterizes Nietzsche's lived approach - is isolation from other folks. In "The Dead," the dissolution of the self is not into the other: it is into death itself, so that Gabriel walks, as so many of the characters walk, in the land of the dead. Gabriel's party is a wake - for life itself. In Portrait of the Artist, the move is more redemptive: Stephen Daedalus's similar dissolution of self he experiences in the moment of epiphany is translated into high art (or at least a respectable villanelle) but note that the writing is moving away from the world of people to perhaps a more glittering sense of the Other as in Stephen's view of the girl who becomes the "subject" of his poem, but the act is isolate - a selfish dissolution of the self. What Joyce does not demonstrate is a full-formed Bohrian complementarity in these binaries, perhaps because he seems, at least in the character of Stephen Daedalus, still looking for an "essence" of beauty. Bohr, in contrast, has little use for essentialism. As Abraham Pais notes, "Again, according to Kant, constructive concepts are intrinsic attributes of the Ding an sich, a viewpoint desperately maintained by Einstein, but abandoned by quantum physicists. In Bohr's words: Our task is not to penetrate into the essence of things, the meaning of which we don't know anyway, but 
rather to develop concepts which allow us to talk in a productive way about phenomena of nature" (230).

Woolf, in contrast, is closer to Bohr in that she finds a way to "talk in a productive way" about the nature of experience itself, and part of that experience is madness. The characters of Septimus and Mrs. Dalloway, taken together, suggest a sense of a reframing of experience that accounts for the larger social forces implicated in the production and reflection of the abundances discussed earlier. Septimus, a decorated war hero, is mad: "So he was deserted. The whole world was clamoring: Kill yourself, kill yourself, for our sakes. But why would he kill himself for their sakes? Food was pleasant; the sun hot; and this killing oneself, how does one set about it, with a table knife, ugly, with floods of blood - by sucking a gas pipe? He was too weak; he could scarcely raise his hand. Besides, now that he was quite alone, condemned, deserted, as those who are about to doing are alone, there was a luxury in it, an isolation full of sublimity; a freedom which the attached never know. Holmes had won, of course; the brute with the red nostrils had won. But even Holmes himself could not touch this last relic straying on the edge of the world, this outcast, who gazed back at the inhabited regions, who lay, like a drowned soldier, on the shore of the world" (92-93).

In contemporary psychodiagnostic nomenclature, what Septimus "has" is acute paranoid schizophrenia, with depressive overtones and suicidal ideation, precipitated by post-traumatic stress disorder. A text book case, he is a candidate for $10 \mathrm{mg}$ Haloperidol TID. However, Woolf's depiction of madness is social, given that Septimus's nemesis, the odious Dr. Holmes, and his replacement, the even more odious Dr. Bradshaw, are monsters of proportion, strict regimens, and no-nonsense rationalism, particularly the latter, who tend to do exactly that which Septimus accuses "them" of: dominate and violate, all with a kindly, knowledgeable, scientific veneer. This figure is the darkest side of Enlightenment thought: the pretentious patriarchal bully, particularly in the character of Dr. Bradshaw, who would be amusing if he were not so deadly to folks such as Septimus, who is simultaneously too shattered and too sensitive. No wonder the theme that dominates the above quote is isolation: Septimus is "deserted," "alone," an "outcast." Like Gabriel in Joyce's "The Dead," he walks in a land of the dead. Not only have his present dealings with the Holmes and Bradshaws of the world exhausted him, he is also unrecovered from the war. In short, Septimus is an exemplar of a fictional character fitting Benjamin's description in "Storyteller" of the folks who came back from World War I - unable to communicate their experiences, reduced to a husked conduit of information at best (83-110). His openness to experience is different than Clarissa Dalloway's: her approach revealed to experience is not so much consummate art as an art of ongoing consummation and that art is the art of the social. Unlike Septimus, who draws deeper into isolation and eventual death, in part as response to the same monstrous folks Clarissa encounters, Clarissa expands into the social, which for her somehow is life: "But to go deeper, beneath what people said (and those judgments, how superficial, how fragmentary they are!) in her own mind now, what did it mean to her, this thing she called life? Oh, it was very queer. Here was so-and-so in South Kensington; some one up in Bayswater; and somebody else, say, in Mayfair. And she felt continuously a sense of their existence; and she felt what a waste; and she felt what a pity; and she felt if only they could be brought together; so she did it. And it was an offering; to combine, to create; but to whom? An offering for the sake of offering, perhaps. Anyhow, it was her gift" (185).

On the surface, she is superficial; her nemesis, the pinched Miss Kilman, accuses her of such at bitter length. However, Clarissa's inner awareness of other's feelings is sophisticated and "intelligent." She is the one who thinks of Sir William Bradshaw when she hears of Septimus's suicide, describing him, entirely too accurately, as "obscurely evil, without lust or sex, extremely polite to women, but capable of some indescribable outrage, that was it - if this young man had gone to him, and Sir William had impressed him, like that, with his power, might he not then have said (indeed she felt it now), life is made intolerable; they make life intolerable, men like that?" (185). She does not reason her way to this conclusion: instead, she applies a sophisticated logic of feeling which requires both a decentering from the self and a recentering into the other - Septimus, in this instance. Her self becomes all the internalized selves around her who she also tries to constantly bring together in an external body - a party that is her "offering." She, too, as Nietzsche with his crowd of identifications and Joyce in his discourse that moves in and out of people never centered, is smeared across the field of people. She recognizes this, saying "every time she gave a party she has this feeling of being 
something not herself, and that everyone was unreal in one way; much more real in another" (171). Yet, she is, as Woolf concludes, "For there she was" - somehow a whole self. This seeming contradiction, which may be the modern contradiction of subjectivity, lends itself, I argue, to a conceptual framing as a Bohrian complementarity: "In general philosophical perspective, it is significant that, as regards analysis and synthesis in other fields of knowledge, we are confronted with situations reminding us of the situation in quantum physics. Thus, the integrity of living organisms and the characteristics of conscious individuals and human cultures present features of wholeness, the account of which implies a typical complementary mode of description" (Bohr 12-13). And in terms of consciousness itself, Bohr says that "the subject-object separation demands special attention. Every unambiguous communication about the state and activity of our mind implies, of course, a separation between the content of our consciousness and the background loosely referred to as "ourselves" but any attempt at exhaustive description of the richness of conscious life demands in various situations a different placing of the section between subject and object" (10).

What Woolf does in her presentation is not only provide a fictionalized description of "the richness of conscious life," she also reveals, in the character of Mrs. Dalloway, who is less a protagonist than a center around which the selves of the other characters move, much as Mrs. Ramsey is in the first part of To the Lighthouse, an approach to living in the world which is replete with complementarities, which are really translations of Enlightenment binaries into post-Enlightenment "non simple wholes." Her prose style could be said to play on the line between subject and object, between self and other, as if she writes in a dizzying series of alternating figure-grounds, and what we get, where the human "is," is on the contour between the contrasts. Importantly, what emerges in Clarissa are not just a new way to understand knowing in the world - Bohr's predominate focus is epistemological - but also provides what may be epistemology's complement, an ontology, a way to exist somehow whole, somehow parceled out in others, somehow sanely coherent and somehow madly perceptive. Whatever the case, her "somehow" always involves a moving towards people while also retaining a kind of consciousness of the abundant "dangers" found on the edge of Enlightenment, including problematic gender relations. In this, she may be attempting to outline what Foucault calls a "mode of subjectification" that, as Paul Rabinow notes, is "one in which an ethos would be a practice of thought formed in direct contact with social and political realities" (xxxii). And Schleifer, in outlining his project for examining the various "abundances" of the Enlightenment period, writes that "In these complexities, the connections between our time and the past that has made us and that we can remake in turn may be discerned. That we should pursue these connections is imperative in the entirety of our conduct and the specificity of our action so that we may recover value and meaning in our knowledge, our wealth, and our experience. Such a pursuit is imperative, even if, as Levinas says, we will never fully and simply or, as Descartes says, clearly and distinctly-retrieve, catch, or coincide with things in a world that seems in many ways overwhelmingly complex, senselessly free, and simply too full" (66).

In conclusion, in all three of these writers - Nietzsche, Joyce, and Woolf - what is evident is that the world of consciousness itself in this period, framed as Bohrian complementarities of sanitymadness and self-other, is, as in the worlds of economics, science, and sociology, replete with overwhelming complexity and senseless freedom, and is, as Schleifer says, "simply too full." However, amid this complexity, freedom, and fullness, possibilities for a humane ordering of the chaos, both within and without, are available. In Nietzsche, freedom of consciousness is a horrible and delightful process: he could be said to teach us to question - and may point out the danger to lived experience if interrogation itself is the only answer. Also Joyce addresses this freedom, but his answer may be too lonely, too isolated, too bound in the world of text to provide an efficacious manner of "remaking" the past into a way to live in the now. Of the three, Woolf, in my analysis, may be closer to offering not just an artful depiction of the complexities of consciousness, but like Bohr in quantum physics, also a new way to account for these abundances, and that way is not to shatter or withdraw from this frightening world, nor to assert some kind of artificial order on it, but instead, to move, as Clarissa moves, in and among people, always risking, always feeling, always making an offering of self to and with the other - and that offering is not to a god or a science but to people themselves. Whatever Clarissa Dalloway is, she is brave in facing herself and the world, and with such bravery, one can almost imagine a day when we all look around and say, delighted, as if at a great party: "And there we are!" 


\section{Works Cited}

Benjamin, Walter. "Storyteller." Illuminations: Essays and Reflections. By Walter Benjamin. Ed. Hannah Arendt. New York: Shocken Books, 1968. 83-110.

Bohr, Niels. The Philosophical Writings of Niels Bohr. Woodbridge: Ox Bow P, 1987.

Defoe, Daniel. Robinson Crusoe. New York: Penguin, 1965.

Foucault, Michel. The History of Sexuality. Vol. 3. The Care of the Self. Trans. Robert Hurley. New York: Vintage, 1986. Vol. 3.

Golden, James L., and Corbett, Edward P.J. The Rhetoric of Blair, Campbell, and Whately. Carbondale: Southern Illinois UP, 1990: 139-260.

Joyce, James. Dubliners. New York: Penguin, 1976.

Joyce, James. Portrait of the Artist as a Young Man. New York: Signet, 1991.

Kaufmann, Walter. "Introduction." The Portable Nietzsche. Ed. Walter Kaufmann. New York: Penguin, 1982. 1-12.

Kern, Stephen. The Culture of Time and Space: 1880-1918. Cambridge: Harvard UP, 1983.

Kuhn, Thomas. The Structure of Scientific Revolutions. Chicago: U of Chicago P, 1996.

Latour, Bruno. We Have Never Been Modern. Trans. Catherine Porter. Cambridge: Harvard UP, 1995.

Nietzsche, Friedrich. "Letters." 1889. The Portable Nietzsche. Trans. and Ed. Walter Kaufmann. New York: Penguin, 1982.

Nietzsche, Friedrich. Genealogy of Morals. Ecce Homo. Trans. and Ed. Walter Kaufmann. New York: Knopf Doubleday, 1989.

Pais, Abraham. Niels Bohr's Times, in Physics, Philosophy, and Polity. Oxford: Clarendon, 1991.

Plotnitsky, Arkady. Complementarity: Antiepistemology after Bohr and Derrida. Durham: Duke UP, 1994.

Rabinow, Paul. "Introduction: The History of Systems of Thought." The Essential Works of Foucault 1954-1984. Ed. Paul Rabinow and Nicolas Rose. New York: The New P, 1997. xi-xlii.

Schleifer, Ronald. Modernism and Time: The Logic of Abundance in Literature, Science, and Culture, 1880-1930. Cambridge: Cambridge UP, 2000.

Woolf, Virginia. Mrs. Dalloway. New York: Harvest, 1981.

Author's profile: Gabriel V. Rupp teaches psychology at the University of Central Oklahoma. His interests in research include communication technology and its relation to consciousness, evolutionary psychology, narrative psychology, and semiotics. His recent publications include entries on de Saussure and structuralism (with Ronald Schleifer) in the The Johns Hopkins Guide to Literary Theory and Criticism, as well numerous articles in PsycCritiques. E-mail: <grupp@uco.edu> 